\title{
A Permissivist Defense of Pascal's Wager
}

\author{
Elizabeth Grace Jackson ${ }^{1}$ (D)
}

Received: 12 October 2020 / Accepted: 18 August 2021

(c) The Author(s), under exclusive licence to Springer Nature B.V. 2021

\begin{abstract}
Epistemic permissivism is the thesis that the evidence can rationally permit more than one attitude toward a proposition. Pascal's wager is the idea that one ought to believe in God for practical reasons, because of what one can gain if theism is true and what one has to lose if theism is false. In this paper, I argue that if epistemic permissivism is true, then the defender of Pascal's wager has powerful responses to two prominent objections. First, I argue that if permissivism is true, then permissivism is true about theistic belief. Second, I show how epistemic permissivism about theistic belief dispels two objections to Pascal's wager: the objection that wagering is impossible, and the objection that wagering is epistemically impermissible.
\end{abstract}

\section{Introduction}

Is there a practical reason to believe in God? Proponents of Pascal's wager argue yes: there is much to gain by believing in God. Table 1 illustrates a common form of the argument:

If God exists, the value of believing in God is infinitely positive, and the value of not believing is infinitely negative. If God does not exist, the gains and losses associated with either course of action ( $f 1$ and $f 2$ ) are both finite, and thus negligible in the face of infinite gains/losses. Thus, one practically ought to believe in God.

Here, I focus on two objections to Pascal's wager. The first I call the impossibility objection-that taking Pascal's wager is impossible because we don't have control over our beliefs. And the view that we cannot directly control our beliefs is orthodox in philosophy. The second I call the irrationality objection. Defenders of this objection argue that, even if we can control our beliefs, beliefs formed for practical

Elizabeth Grace Jackson

lizjackson111@gmail.com

1 Department of Philosophy, Ryerson University, 350 Victoria Street, Toronto, ON M5B 2K3, Canada 


\begin{tabular}{llll}
\hline & $\begin{array}{l}\text { God exists } \\
(\operatorname{Pr}=\mathrm{n})\end{array}$ & $\begin{array}{l}\text { God doesn't exist } \\
(\operatorname{Pr}=1-\mathrm{n})\end{array}$ & EV \\
\hline Believe in God & $\omega$ & $f 1$ & $\omega$ \\
Don't believe in God & $-\omega$ & $f 2$ & $-\omega$ \\
\hline
\end{tabular}

reasons are epistemically irrational. Advocates of the wager have responded to these objections. However, I argue that if epistemic permissivism is true, then we can improve on their responses; stronger, less concessive responses are available. ${ }^{1}$

My argument has three steps. First, I argue that if epistemic permissivism is true, then epistemic permissivism about theism is true (Sect. 2). Second, I argue that if epistemic permissivism about theism is true, then one has control over their theistic beliefs, i.e. the impossibility objection fails (Sect. 3). Third, I argue that if epistemic permissivism about theism is true, then the belief formed as a result of wagering is epistemically rational, i.e. the irrationality objection fails (Sect. 4).

Some background assumptions and clarifications about Pascal's wager are worth noting before we proceed. First, for the argument to work, $n$, the wagerer's credence that God exists, must be non-zero (and non-infinitesimal). The wager will have little purchase for those completely convinced that God does not exist, assigning atheism probability 1 (or infinitely close to 1 ). In general, I'll take the perspective of someone for whom God's existence is a live (epistemic) possibility.

Second, the argument requires that there is a meaningful way to compare infinitely good outcomes using decision theory. As Duff (1986) and Hájek (2003) point out, without a way to compare infinities, Pascal's wager has the counterintuitive consequence that all decisions have infinite expected value. However, this is a structural, rather than a substantive problem for the wager, since it is clearly rational to go for a higher, rather than a lower, chance at getting infinite utility. And as Jackson and Rogers (2019) and Chen and Rubio (2020) have argued, decision theory can accommodate this datum. ${ }^{2}$

Finally, I focus on the basic decision of whether to be a theist. Two points of clarification about this. One, things get more complex when the possibility space is divided more finely to include specific religions, as the well-known many-gods objection states. However, the decision of whether to be a theist is meaningful and

\footnotetext{
${ }^{1}$ The connection between pragmatic arguments for theism and permissivism goes back to William James (1896/1979), who argued that if a matter cannot be settled by the evidence, we can exercise our will to believe and even do so 'lawfully', i.e. without compromising epistemic rationality. Arguably, even Pascal himself was concerned with a kind of permissive case, where one's evidence is balanced between Christianity and atheism (as the only two live options). For further discussion of James, permissivism, and rational belief at will, see Adler (2002, 59-63). Thanks to Alex Jech for helpful discussion.

${ }^{2}$ Note also that wagering may not guarantee one eternal salvation, and not wagering may not guarantee one ends up in hell. Further, an eternal blissful afterlife isn't entailed by the existence of God. However, once we've modified our decision matrix to account for the idea that probability matters, even in the infinite case, all we need is a relatively weak claim: that wagerers are more likely than non-wagerers to get infinite utility. Thanks to an anonymous referee for encouraging me to clarify this point.
} 
can be treated in its own right. Responding to the many-gods worry is not one of my goals. Further, once decision theory accommodates the idea that not all infinities are decision-theoretically equivalent, then all else equal, it will be rational to practice the religion with an infinite afterlife that one takes to be the most probable, so the many-gods objection can be incorporated into the wagerer's decision matrix. ${ }^{3}$ (For more on my response to the many-gods objection, see Jackson \& Rogers, 2019.) ${ }^{4}$

Two, my decision to focus on belief that God exists raises the question: does God want mere belief? Would merely believing in God really lead to something infinitely positive? The answer will vary depending on one's theological commitments, but probably, theistic belief by itself isn't sufficient for salvation-e.g. on the Christian tradition, demons believe in God, but they aren't saved..$^{5}$ That said, belief may be necessary for salvation, or weaker, an important aspect of a religious commitment, perhaps one that is necessary in particular circumstances. For example, for most adults with full cognitive capacities, maybe God desires belief in God coupled with a commitment to God. This commitment will result in accepting, or acting as if, God exists, by attending religious services, praying, participating in a religious community, etc. However, the two objections considered in this paper-whether wagering is possible and whether it is epistemically rational-aren't a problem for committing to God; they seem like a special problem for belief. Thus, this paper provides an answer for any theological tradition on which belief is a key component, even if insufficient for salvation. I now turn to our first task: explaining epistemic permissivism and its application to theistic belief.

\section{Epistemic Permissivism and Theistic Belief}

Epistemic permissivism is the view that there are evidential situations that rationally permit more than one (incompatible) attitude toward a proposition. ${ }^{6}$ For example, epistemically rational paleontologists might share evidence but disagree about what killed the dinosaurs; epistemically rational jurors might share evidence but disagree about who committed a crime. Or consider a single juror: if she faces inconclusive

\footnotetext{
3 The "all else equal" qualification is crucial, because, if two religions aren't otherwise equal, there are other things besides probability that affect which religion one should choose. For example, as Rota (2016a: fn. 36) notes, the probability of obtaining infinite utility or disutility in the cases of the religion's truth or falsity is also a key consideration. Further, if one thought a certain religion had a better heaven (or a worse hell) than another religion, that should also affect one's wager. See Jackson and Rogers (2019) for an example of how some of these additional considerations might be factored into one's decision matrix. Thanks to an anonymous referee for encouraging me to clarify this point.

4 Other responses to the many-gods objection include Martin (1975), Lycan \& Schlesinger (1989), Jordan (1991), Bartha (2012). For a rejoinder on behalf of the objection, see Duncan (2018).

5 James 2:19. Thanks to anonymous referees for raising this objection.

6 The attitudes must be incompatible because that one can have a belief that $p$ and a credence in $p$ at the same time doesn't commit one to permissivism. Defenders of permissivism include Kelly (2013), Schoenfield (2014; 2019), Titelbaum \& Kopec (2019), Roeber (2020). Defenders of uniqueness, the denial of permissivism, include White (2005), Matheson (2011), Greco \& Hedden (2016), Dogramaci \& Horowitz (2016). For overviews, see Kopec \& Titelbaum (2016) and Jackson \& Turnbull (forthcoming).
} 
evidence, then both belief that Smith is guilty and disbelief that Smith is guilty might be rationally available to her. Or her evidence might be "balanced" to allow both belief and withholding belief.

The case involving a single juror is an example of intrapersonal permissivism, the strand of permissivism I'm concerned with in this paper. Intrapersonal permissivism involves a single person and her evidence. More precisely, intrapersonal permissivism is the view that there are evidential situations in which a single person can rationally adopt more than one incompatible attitude toward a proposition. Further, I focus on permissivism about belief-attitudes: belief, withholding belief, and disbelief, as opposed to credal permissivism. ${ }^{7}$ Thus, I assume intrapersonal belief permissivism: that there are evidential situations in which a single person can rationally adopt more than one belief-attitude toward a proposition (but not both at once). My thesis is a conditional claim, and the antecedent is that intrapersonal belief permissivism is true; I won't defend the antecedent here, but it has been defended by Podgorski (2016), Roeber (2019, 2020), Jackson (2021), and Callahan (forthcoming).

This brings me to my first thesis: if intrapersonal belief permissivism is true, then intrapersonal belief permissivism about theistic belief is true. ${ }^{8}$ More specifically, the consequent of this thesis is that there are evidential situations in which a single person can rationally adopt more than one belief-attitude toward the proposition God exists. And this consequent is actually slightly stronger than this-I claim that these evidential situations are relatively widespread. The precise claim I will argue for is:

Claim 1: If intrapersonal belief permissivism is true, then there are relatively common evidential situations in which a single person can rationally adopt more than one belief-attitude toward the proposition God exists.

There are several reasons to think that if this strand of permissivism is true, then many actual bodies of evidence are permissive about theistic belief.

First, debates about God's existence have a long history, with powerful evidence on both sides. There are a number of theistic arguments, including the ontological argument, cosmological argument, design argument, fine-tuning argument, moral argument, evolutionary argument against naturalism, and others. ${ }^{9}$ There are also atheistic arguments, including the problem of evil (McBrayer \& Howard-Snyder, 2013) and the argument from divine hiddenness (Schellenberg, 1993; Howard-Snyder \& Moser, 2002). Others have argued that the idea of God is incoherent (Mizrahi, 2013), and that there's no need to posit divine being(s) if the universe has a perfectly good natural explanation (Wielenberg, 2009). On both sides, the arguments

\footnotetext{
7 Although I am open to the possibility of extending my arguments to credences. For more on how the relationship between belief and credence interacts with permissivism, see Jackson (2019: 2480-2).

8 Raleigh (2017) and Kopec (2015) defend a version of intrapersonal permissivism based on the possibility of self-fulfilling beliefs. Since believing in God doesn't make it more likely that God exists, I'll set this strand of intrapersonal permissivism aside. Thanks to Marc-Kevin Daoust.

9 See Walls \& Dougherty (2018).
} 
have been presented, objected to, reframed, objected to again, responses given... the process continues. There are also distinct versions of many of the above arguments, e.g. the logical problem of evil and the evidential problem of evil, Anselm's ontological argument and Plantinga's ontological argument, and the Kalam cosmological argument and Thomistic cosmological arguments. The same debates have occurred with the various versions of each argument, each new argument succeeded by a long string of objections and replies.

Second, there is widespread disagreement about God's existence. In the overall world's population, there are more theists than atheists (Keysar \& Navarro-Rivera, 2017), and historically, a majority of philosophers were theists (Miguel, 2020). Today, however, according to a survey done by Bourget and Chalmers, roughly $70 \%$ of professional philosophers are atheists and 15\% are theists (2014: 476). Though when we narrow our focus to philosophers of religion-those who specialize in questions about God's existence- the same survey found that around 70\% are theists. There are differing explanations for these facts, and here, I don't take a stand on which explanation is correct or which group (if any) is more likely to reliably form theistic beliefs. I mention these statistics to show (i) that there is widespread disagreement on the existence of God and (ii) that there are smart, informed people on both sides of the debate. The pervasive disagreement and lack of consensus make theism a good candidate for an issue that is likely to be permissive.

Third, many atheists, agnostics, and theists appear to be epistemically rational, even when they are aware of the same (or similar) evidence that bears on God's existence. The question of whether God exists is dissimilar to questions in which our evidence clearly supports a particular answer, e.g. the question of whether the earth is flat. When it comes to positions on God's existence, there is epistemic symmetry: no group has an obvious general epistemic advantage over the other. This isn't to assume that we all have the same evidence about whether God exists. It just is to say that, among the diversity of bodies of evidence, many rationalize distinct opinions on theism. This may be one reason that theism is frequently cited as a permissive case, and is even used as a way to motivate permissivism via example. ${ }^{10}$ If bodies of evidence are permissive, then theism seems like a paradigm case of a proposition that would be permissive.

Recall that my claim isn't merely an existential one, i.e. there exists a body of evidence that is permissive about theism. Rather, I maintain that many bodies of evidence possessed by actual humans are permissive about theism. Why think this? Most humans are not in a position in which God's existence is completely obvious, but also not in a position where is it entirely clear that God doesn't exist. This explains the data above-the long history of arguments about theism, the rampant disagreement, and the apparent rationality of theists, atheists, and agnostics. I make no claims about whether our evidence is permissive across a wide range of propositions; my focus is merely on theistic belief. In this sense, my claim is limited. My claim is only about the frequency of bodies of evidence that are permissive about a single proposition— that is, God exists.

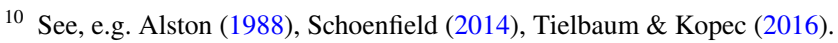


The divine hiddenness literature also supports the thesis that our evidence is permissive about theism. Many philosophers in this literature argue that one important sense in which God is hidden is that our evidence for theism is ambiguous. For example, John Hick (1966) argues that many are in an evidentially indeterminate situation concerning God's existence; Swinburne (1979), Murray (2002), Cullison (2010), and others agree. (Relevant to the next section, some of these authors also suggest that part of the reason God allows evidential ambiguity is that it enables humans to freely choose to believe in God.) Their point is not that our evidence makes theism irrational. Rather, the thought is that some are completely rational in their agnosticism or atheism-to use Schellenberg (1993)'s terminology, they are non-resistant non-believers. Part of what makes the divine hiddenness question so serious and important is that the evidence for theism indeed doesn't seem decisive. This further supports the idea that many bodies of evidence possessed by actual humans are permissive regarding theism. ${ }^{11}$

One might object that many of the above arguments seem to apply to the interpersonal case, but not the intrapersonal case. For example, maybe disagreement about theism is the result of individuals' differing epistemic standards (Schoenfield, 2014). Standards-permissivism is the view that rational belief is determined both by an person's evidence and by the epistemic standards that one uses to weigh and interpret that evidence. But as long as each person's standards are held fixed, standards-permissivism only motivates interpersonal permissivism about theism. ${ }^{12}$

In reply, first, given that we've assumed intrapersonal permissivism is true, the above considerations also motivate that theism is intrapersonally permissive. Whether God exists is a very difficult question, our evidence is inconclusive, and many people second-guess or even change their views about theism over the course of their lives. Second, consider your own view on whether God exists: you may be a theist, an agnostic, or an atheist. Would you be epistemically irrational if you had a different view? Does your evidence force one perspective upon you? Most of us will likely answer no: holding my evidence fixed, I wouldn't be epistemically rational if I had a different opinion on God's existence. Finally, Callahan (forthcoming) argues that standards-permissivism lends itself to intrapersonal permissivism. On Callahan's view, epistemic standards aren't simply passive aspects of a thinker's psychology, but are a result of our choices and active commitments. This motivates both interpersonal and intrapersonal permissivism, since a single person's epistemic standards can grow and develop over time.

Even if Claim 1 is true, there may be people whose evidence decisively rationalizes a particular attitude about God's existence. Religious mystics who take themselves to have had undeniable experiences of God or miracles ought to be theists, given their evidence. And others may have evidence that points so strongly toward atheism that they cannot be rational in taking a different attitude. However, these cases are exceptions, rather than the rule. Most of us have not witnessed miracles but also don't have evidence that clearly favors atheism. I am focused on the average

\footnotetext{
11 Thanks to Dustin Crummett.

12 Thanks to Marc-Kevin Daoust.
} 
case and the standard body of evidence. Further, recall that my argument is also targeted at those for whom God's existence is a live epistemic possibility. Then, assuming some bodies of evidence are permissive, many actual bodies of evidence are permissive about theistic belief.

\section{The Impossibility Objection}

In this section, I argue that intrapersonal permissivism about theistic belief entails that the impossibility objection to Pascal's wager fails. This is because in intrapersonally permissive cases, we have significantly more control over our beliefs than philosophers normally think. As Roeber (2019: 837) puts it, in these cases, "there is no reason why you can't believe p at will."

\subsection{The Objection}

The impossibility objection is made by several authors, and although they are divided on whether a version of the wager is ultimately successful, they are all clear that we cannot, in any sense, form a belief at will based on Pascalian considerations. For instance, while discussing the wager, Mackie (1982: 201) notes "you cannot believe by simply deciding to do so...direct voluntary belief is not [possible]." Duff (1986: 108) states that "the wager does not give us reason to believe in God, for we cannot simply decide to believe in God." Jones (1998: 173) presents an extended version of this objection:

It is important for understanding the nature of the Wager that we see that even the ideal reader will not, upon reading it, form a belief in the articles of faith. This should not be surprising. We cannot consciously form a belief because we think that forming it would be good for us, or because we want to form it. We cannot form a belief and at the same time realize that we are believing it because it will confer benefit on us. The ideal reader will not form a belief in the articles of faith upon reading Pascal's Wager any sooner than she will respond to an offer of money for the belief that the earth is flat.

Jones, like most authors who make this objection, rests the objection on the premise that doxastic voluntarism is false. Doxastic voluntarism is (roughly) the thesis that it is possible to control one's beliefs directly, voluntarily, or at will (we'll precisify this soon). Jordan (2006: 38) explicitly invokes doxastic involuntarism in his statement of this objection. After presenting the impossibility objection, he states, "it is clear enough that doxastic voluntarism is implausible. Assurance of this can be had by surveying various propositions that one does not currently believe, and seeing if any lend themselves, directly and immediately, by a basic act of the will, for belief." $\mathrm{He}$ considers an argument presented by Williams (1973), that states that doxastic voluntarism is false because it is impossible to believe a certain proposition but know that the proposition is false. He continues, "Perhaps a proponent of doxastic voluntarism might avoid Williams's objection by proposing a restricted view that limits belief 
at will to only those propositions that we know neither to be true nor false. In any case, even if conceptually possible, this restricted doxastic voluntarism is implausible" (39).

The authors who motivate the impossibility objection via doxastic involuntarism are in good company, since the orthodox view is that we cannot control our beliefs directly. ${ }^{13}$ For instance, Alston (1988) offers an extensive argument for doxastic involuntarism; others, such as Bennett (1990: 87), Hieronymi (2009: 149), and Shah and Velleman (2005: 502) even take doxastic involuntarism as a datum. While there are several arguments offered for doxastic involuntarism in the literature, it is often motivated (at least in part) by examples such as the following from Alston (1988: 263):

[I] contend that we are not so constituted as to be able to take up propositional attitudes at will. My argument for this, if it can be called that, simply consists in asking you to consider whether you have any such powers. Can you, at this moment, start to believe that the U.S. is still a colony of Great Britain just by deciding to do so. If you find it too incredible that you should be sufficiently motivated to try to believe this, suppose that someone offers you $\$ 500,000,000$ to believe it, and you are much more interested in the money than in believing the truth... Can you switch propositional attitudes toward that proposition just by deciding to do so? It seems clear to me that I have no such power.

Other authors motivate doxastic voluntarism with similar cases: Suppose I offer you a bunch of money to believe $2+2=5$, or that the sky is green. You cannot do so; thus, you cannot believe at will and doxastic voluntarism is false. ${ }^{14}$

If doxastic voluntarism is indeed false, then this creates problems for certain versions of Pascal's wager. For instance, you might think Pascal's wager is similar to Alston's case: I offer you a large reward to change one of your beliefs. But you cannot believe at will, thus you cannot wager. And if ought implies can, then it's not the case that you ought to wager, either. Wagering thus is both impossible and not rationally required.

\subsection{The Concessive Response}

Many of those who write on this objection to Pascal's wager, including several of the authors noted above, argue that the best way to answer this objection is to take the focus away from belief and instead to focus on action. This is, arguably, a response advocated by Pascal himself, when he says that even if one cannot believe one ought to act as if one believes, by "taking holy water, having masses, etc." (1662: 233). As Jones (1998: 175) notes, "Since Pascal realizes that our conscious control over our

\footnotetext{
13 Proponents of doxastic involuntarism include Williams (1973), Winters (1979), Alston (1988), Bennett (1990), Scott-Kakures (1994), Shah \& Velleman (2005), Hieronymi (2006, 2009), and Setiya (2008).

14 Plantinga (1993: 24), Feldman (2001: 80), Russell (2001: 42), and Hieronymi (2006: 45-46) all use this kind of case to motivate doxastic involuntarism. Ryan (2003: 63) argues that this motivation is unsuccessful; Nottelmann (2006: 562) responds to Ryan.
} 
beliefs can at best be mediate, he has given a practical argument, an argument telling us to do something, to act in a certain way which will bring about belief." Duff (1986: 108) makes similar remarks. Golding (1994: 115) argues the wager gives us reason to "pursue a good relationship with God" and Rota (2016a, b) presents a version of the wager on which we should "commit to God."

These responses are all limited, in that they (i) quickly concede that doxastic voluntarism is false and (ii) maintain that instead of directly changing our beliefs, the wager should instead motivate us to make lifestyle changes, such as going to church, praying, participating in religious communities and rituals, etc.

\subsection{The Powerful Permissive Response}

If permissivism is true, then we have much more control over our beliefs than these authors suggest. More specifically, I argue that in permissive cases, we have either direct or what I call 'semi-direct' control over our beliefs. In response to the wager, many of us can alter our beliefs relatively immediately - we need not fall back onto action. In other words, I'll argue for the following claim:

Claim 2: If there are relatively common evidential situations in which a single person can rationally adopt more than one belief-attitude toward the proposition God exists, then people often have either direct or semi-direct control over their theistic beliefs.

The doxastic voluntarism literature uses many terms that pick out various sorts of control, e.g. "direct" control, "voluntary" control, "intentional" belief, belief "at will." To clarify the kinds of control of interest, I begin by demarcating four kinds of control we may have over beliefs (borrowing from Alston's terminology): direct control, semi-direct control, long-range control, and indirect influence. Those in the previous literature on Pascal's wager have fallen back on the third and fourth strands; here, I argue that we have either direct or semi-direct control over theistic belief in intrapersonally permissive cases.

Direct control is the kind of control that most humans have over movements like raising their hands. Able-bodied humans can raise their hands in a swift, uninterrupted act, without being disrupted by activity directed at other goals. If I offer you money to raise your hand, you can do so immediately and easily. This is the kind of control often associated with so-called "basic" actions. Alston (1988: 260) defines basic actions as "actions we perform 'at will,' just by an intention, volition, choice, or decision to do so, things we 'just do,' not 'by' doing something else voluntarily." Hieronymi (2006: 48) provides a similar definition: "Basic actions are 'immediate' in that they can be performed without having to do anything else to perform them." Thus, when I say one has direct control over their beliefs, I mean that believing is a basic action. In the Pascalian case, this would look like forming a theistic belief immediately and directly in response to the wager. 
Hieronmyi rightfully notes that we shouldn't equate basic action and voluntary action. She argues that we have control over both hand raising and preparing dinner: "The fact that I cannot prepare dinner without chopping the vegetables, turning on the burner, and heating the oil does not render my action any less 'voluntary,' in the relevant sense. It simply renders it non-basic" (2006: 48). This point is important. There are certain actions-like preparing dinner, rearranging the furniture, or going for a run-that are more 'clunky' than hand-raising. While performing basic actions is easier than performing non-basic actions, non-basic actions are no less voluntary. I will call the kind of control we typically have over these non-basic but voluntary actions semi-direct control. We cannot perform the action immediately in one uninterrupted act; these tasks are more complex, stretched out over a longer time period, and more difficult to perform. But they are no less under our voluntary control. In the Pascalian case, semi-direct control would look like forming a theistic belief as a result of a short-term process, maybe one of deliberation or of focusing on certain aspects of one's evidence.

A third variety of control is long-range control. Long-range control is similar to semi-direct control in that it is non-basic and occurs over time. However, there are two main differences. First, one exercises long-range control over a much longer period than semi-direct control. Second, upon intending to phi, the probability that one phi-s is lower if one merely has long-range control over phi-ing, than if one has semi-direct control. Examples of things one has long-range control over include one's fitness level or blood pressure. Making dinner upon intending to do so is much more likely to be successful than becoming more fit or changing one's blood pressure. Nonetheless, one has some kind of influence over one's blood pressure and fitness level. In the Pascalian case, long-range control would amount to a long-term project to believe that God exists, similar to what some of the authors discussed in Sect. 3.2 propose-e.g. attending church, participating in a religious community, and gathering evidence that supports theism, with the eventual goal of becoming a theist.

A final kind of control is indirect influence. This kind of control doesn't involve an intention to believe a particular proposition at all. Rather, this kind of control is what one has over one's doxastic habits and tendencies. One can make an effort to become a more curious or open-minded person without trying to form or give up token beliefs, as one can attempt to become a healthier person without explicitly trying to change their blood pressure by a certain amount. This category is borrowed directly from Alston (1988: 277ff), who describes it as including "such activities as training myself to be more critical of gossip, instilling in myself a stronger disposition to reflect carefully before making a judgment on highly controversial matters, talking myself into being less (more) subservient to authority, and practicing greater sensitivity to the condition of other people" (279). Those that take Pascal's wager in this way don't have any intention to eventually form certain beliefs, but rather may make a general commitment to act in certain ways, e.g. spending more time studying religious claims or pursuing a relationship with God, as Golding (1994) and Rota (2016a, b) suggest.

My goal in this section is to argue that, in cases that are intrapersonally permissive about theism, persons have either direct or semi-direct control over their theistic 
belief-attitudes. That persons have direct control is the stronger and more controversial claim; while I think that permissivism enables this sort of control in at least some cases, I am unlikely to convince the skeptical reader who buys into the doxastic involuntarism orthodoxy. For such a reader, I hope to at least motivate that permissivism enables the possibility of semi-direct control—even if believing isn't like hand raising, in permissive cases, we can still form beliefs as a result of a process of deliberation or evidence-focusing. And, as Hieronymi argues, this is relevantly voluntary.

To see why I think permissivism enables a stronger sense of control, first note that many of the cases used to motivate doxastic voluntarism are clearly impermissive. If I give you a million dollars to believe that the earth is flat or that the US is still a colony of Great Britain, I've motivated you to believe a proposition that you take to be obviously false: you should disbelieve it, given your evidence. But the situation isn't the same if you are truly torn about some matter. Suppose you are deciding whether it should be illegal for individuals to own firearms. You find yourself waffling between belief and withholding belief: sometimes you think it should be illegal, but at other points, you find yourself withholding belief instead. If there is a practical incentive to believe this proposition (maybe your fiancé's family are all strong proponents of gun control) then it's much more plausible you could bring yourself to believe this via direct or semi-direct control. If both attitudes are "live" for you, believing on a practical basis is no longer clearly and obviously impossible (see Steup, 2017: 2682-3).

The authors who use impermissive cases to motivate the impossibility objection do not consider the possibility of permissive cases, or if they do, they dismiss them quickly and without much argument. For instance, Jordan (2006: 39) simply notes "this restricted doxastic voluntarism is implausible." Alston (1988: 266) argues that in these cases "the situation is better construed in some way other than as initiating a belief at will." Alston suggests that maybe the case was never permissive after all and forming the belief was inevitable, or, alternatively, you aren't believing the proposition in question but instead doing something else, like accepting it (see also Buchareff 2004). But with so little argument, it's hard to see why we should automatically assume these can't be cases of genuine belief; these arguments appear to be simply re-stating the involuntarist thesis.

Further, several authors, including Raz (1999), Ginet (2001), Frankish (2007), Nickel (2010), McHugh (2014), Peels (2015), Steup (2012, 2017), Roeber (2019, 2020), have argued that we can exercise voluntary control over our beliefs in intrapersonally permissive cases. ${ }^{15}$ Consider two cases from Nickel (2010):

My roommate, a serious and sensible person, announces to me that he has just been outside and seen a three-foot lizard in the driveway. I have never seen

\footnotetext{
15 While they don't all explicitly use the language of 'permissive cases' (many do), they all seem to have intrapersonally permissive cases in mind. Peels, for instance, focuses on self-fulfilling beliefs, and as Raleigh (2017) and Kopec (2015) have noted, self-fulfilling beliefs are a good candidate for intrapersonally permissive beliefs.
} 
such a large lizard in the area before, and I have some reason to doubt whether any lizards of that size live naturally in the area (Nickel, 2010: 313).

I have lived for three years in an area where I have never heard the sound of a train, although I have observed some seemingly unused train tracks. I do not know whether the train tracks have fallen into disrepair. One morning, as I am working, I hear the sound of a train whistle, and I feel the distinctive vibration of a locomotive (Nickel, 2010: 313-314).

In both of these cases, Nickel argues that you may believe the propositions in question-your roommate's testimony about the lizard or that there is a train nearby. However, you are also perfectly rational if you decide to suspend judgment. Your evidence leaves things open, so you can decide how to respond.

Roeber considers cases where your evidence for some proposition is slowly improving. Initially, it requires you to suspend judgment, and eventually, it requires you to believe the proposition. However, if the evidential improvements are gradual enough, there will be a point at which you can rationally either suspend or believe. Consider:

You're walking across a meadow. There's a brownish object in a distant tree, but you can't tell what it is. Your daughter says it's a bird and your son says it's a big piece of trash - a plastic bag or something like that. This is New Jersey so there's a real question here. You walk toward the object to see who's right. As you get close it flies away. In this case-and countless more like it-you go by gradual improvements in your evidence from a situation where you are rationally required to suspend judgment on some proposition to a situation where ...you are rationally required to believe that proposition. And as your evidential situation improves, your evidence provides less and less support for suspension of judgment, and more and more support for belief. Moreover, on this view, if your total evidence supports suspension and belief equally well while ruling out disbelief, suspension and belief will both be rationally permissible (Roeber, 2019: 837-8).

In these cases, there's a point where one's evidence is sufficient for belief, but doesn't compel belief. In the lizard case, for instance, one could choose to believe one's roommate or be agnostic. Since the evidence underdetermines what one should believe, there is room to step in and choose what to believe. A number of these authors-including Ginet, Frankish, Nickel, and Roeber-maintain that these are cases of direct control.

Further, several of these authors, most explicitly Frankish (2007) and McHugh (2014), argue that not only that permissivism enables doxastic control, but in permissive cases, when the epistemic 'leaves things open', the practical can motivate belief (see also Cockayne et al., 2017). Plausibly, people in these cases are motivated by both practical and epistemic considerations. McHugh (2013: 1127) discusses a case in which your friend is accused of a terrible crime. There is some significant evidence your friend did it, which, by itself, would normally convince you that your friend is guilty. However, your friend also has a pretty reasonable alibi supported by several witnesses. In this case, McHugh thinks that, when deliberating about whether your friend is innocent, "you can take into account 
a non-evidential consideration-namely the good of believing that your friend is innocent," which would be especially good if your friend is in fact innocent. Further, if you believe your friend is guilty and they are innocent, this will have profoundly damaging effects on your friendship (1127). From an epistemic perspective, there are multiple reasonable doxastic attitudes one can take, given the evidence. Then, practical reasons seem like they can play a role in your decision about what to believe.

Finally, consider a case from Leary (2017), who argues that one could be motivated to believe that God exists for practical reasons:

Mary is usually sceptical of other people's testimony and arguments. She didn't give religion much thought growing up, but at college Mary comes to believe that she would be happier if she were to believe that God exists, and that this is a strong reason to do so. While taking a philosophy class, she reads Aquinas's and Anselm's arguments for the existence of God and she befriends a student who tells her about his experiences of divine revelation. While this would usually not be enough to convince Mary (given her sceptical nature), because she recognizes the practical benefit of believing in God as a reason to do so, this causes her to be more swayed by those arguments, and she ends up believing that God exists (Leary, 2017: 538).

Leary concludes that practical reasons can motivate someone to believe in God. Leary does not even rely on permissivism to establish this-in fact, as part of her case, Mary's epistemic reasons normally wouldn't have persuaded her, which suggests they aren't permissive. If instead, Mary's epistemic reasons underdetermine her decision between belief and agnosticism, it's even more plausible that Mary could believe in God for practical reasons.

The only attempt I am aware of to block the permissivist route to doxastic control is Sylvan (2016). However, he does so by arguing against the possibility of (intrapersonally) permissive cases, rather than against the premise that permissivism clears space for doxastic voluntarism. Sylvan doesn't attack the conditional claim, that if permissivism is true, then we have voluntary control over some of our beliefs. Thus, Sylvan's arguments don't affect the main moves in this paper, and Roeber (2020) provides a compelling response to Sylvan on behalf of the permissivist. Generally, then, it's not at all clear that anyone in the doxastic voluntarism literature provides reasons to think that we cannot have direct or semi-direct control our beliefs in intrapersonally permissive cases.

Since many of the above authors are interested in direct control, it is worth explicitly considering what semi-direct control in these cases might look like. This includes at least two possibilities. One, someone might undergo a process of deliberation that results in the belief. Two, someone might focus on certain pieces of their evidence that support the belief. Consider the case from McHugh in which your friend is accused of a crime. You could demonstrate semi-direct control over your belief by deliberating in a way that makes you more likely to form the belief that your friend is innocent, e.g. by giving yourself an abductive argument based on your past experiences with your friend and their character. Alternatively, you might focus 
on the evidence regarding your friend's alibi and the witnesses that support it, and in doing so, form the belief your friend is innocent.

This case is similar to the famous Cliffordian shipowner, who initially doubted his ship was seaworthy, as she was "old, and not overwell built at the first; that she had seen many seas and climes, and often had needed repairs." However, via deliberation and evidence-focusing, he overcomes these doubts. "He said to himself that she had gone safely through so many voyages and weathered so many storms that it was idle to suppose she would not come safely home from this trip also. He would put his trust in Providence... he acquired a sincere and comfortable conviction that his vessel was thoroughly safe and seaworthy; he watched her departure with a light heart..." (Clifford, 1877: 289). While Clifford ultimately criticizes the shipowner for forming this belief, changing our beliefs in this way need not be a bad thing.

Consider an alternative case: suppose there is a new member of your department, and you've gotten a bad impression of them. You have some small pieces of evidence that they aren't a good person-maybe they don't smile much, and once you waved to them and they ignored you, but you're not sure if they saw you-nothing conclusive. Upon realizing you've come to think that they are an unfriendly person and that your evidence for this isn't conclusive, you might purposefully attempt to change your attitude about them, especially if you think (i) it would be better to think well of them and (ii) your evidence doesn't demand that you consider them a bad person. You could change your belief by telling yourself that your evidence is minimal, focusing on any evidence you might have that they are a kind and good person, etc. ${ }^{16}$ It's hard to see why we should rule out the possibility of semi-direct control in these cases - in fact, altering our beliefs in this way seems familiar, if not common.

What would direct or semi-direct control look like when it comes to belief in God? First, it is worth noting that theism is, for most people, more fundamental and worldview-shaping than questions about whether your colleague is a nice person or whether a particular object is a bird or a bag. This is not grounds to rule out direct or semi-direct control over our theistic beliefs. Nonetheless, it may look slightly different. Pittard (2020) describes the phenomenon of being pulled between two worldviews (what he calls 'epistemic frames'), rather than merely between two attitudes toward a proposition. When we exercise direct or semi-direct control toward propositions that are more fundamental and closely interconnected with our other beliefs, this might also involve changing not just our attitude toward a single proposition, but our attitude toward many propositions, as we are picking between two ways of viewing the world.

Peter van Inwagen (1994) describes a phenomenon very similar to this one in an autobiographical article about how he came to be a theist. His remarks are worth quoting at length:

First, I can remember having a picture of the cosmos, the physical universe, as a self-subsistent thing, something that is just there and requires no expla-

$\overline{{ }^{16}}$ Thanks to Jenny Munt for this case. 
nation. When I say 'having a picture,' I am trying to describe a state of mind that could be called up whenever I desire and was centered on a certain mental image. This mental image-it somehow represented the whole world-was associated with a felt conviction that what the image represented was self-subsistent. I can still call the image to mind (I think it's the same image), and it still represents the whole world, but it is now associated with a felt conviction that what it represents is not self-subsistent, that it must depend on something else, something that is not represented by any feature of the image, and must be, in some way that the experience leaves indeterminate, radically different in kind from what the image represents. Interestingly enough, there was a period of transition, a period during which I could move back and forth at will, in the "duck-rabbit" fashion, between experiencing the image as representing the world as self-subsistent and experience the image as representing the world as dependent (van Inwagen, 1994: 35).

Later in the same article, he describes this duck-rabbit experience as both "recurrent" and a central part of his conversion experience. This may be exactly what direct (or semi-direct) control looks like when it comes to fundamental worldview questions like theism: we can move between seeing the world in two ways; both are "live" possibilities for us, and van Inwagen even claims that he could move in between them "at will." And again, this may not merely involve an attitude toward a single proposition, but between two coherent sets of propositions, both that purport to explain one's evidence. ${ }^{17}$

On this final possibility, it is also worth noting that, in normal circumstances, many may treat worldview questions as settled for various practical or epistemic reasons. Nonetheless, many of us could get ourselves into a state of mind similar to van Inwagen's, by thinking hard about the possibility of the other worldview, imagining what it would be like if that worldview were true, focusing on our evidence that supports the worldview, etc. In fact, I would contend that many could even do this without gathering evidence in favor of the other worldview. ${ }^{18}$ Again, my claim is not universal-some may be so convinced of theism or atheism that this wouldn't be possible without a radical change in evidence. It is simply a claim about many bodies of evidence.

In this section, I've argued that:

\footnotetext{
${ }^{17}$ Note that it's not clear whether van Inwagen is describing moving between beliefs (i.e. the world is self-subsistent vs. the world isn't self-subsistent) or moving between seemings (i.e. whether the world seems self-subsistent). While van Inwagen does speak of representations, and beliefs are normally taken to be representational states, the duck-rabbit metaphor suggests he has seemings in mind. However, either interpretation fits with my argument. If van Inwagen is talking about beliefs, then this is a plausible example of direct doxastic control. If van Inwagen is merely talking about seemings, then this is a plausible example of semi-direct control. One might exercise semi-direct control via focusing on a particular seeming, which, when combined with evidence focusing and deliberation, can lead to forming the corresponding belief. Thanks to an anonymous referee for suggesting this distinction.

${ }^{18}$ See Jackson (2021) for a further defense of this claim in non-theistic cases, and an explanation of how it supports intrapersonal permissivism.
} 
Claim 2: If there are relatively common evidential situations in which a single person can rationally adopt more than one belief-attitude toward the proposition God exists, then people often have either direct or semi-direct control over their theistic beliefs.

In closing, I'll address two potential objections to Claim 2. First, one might point out that permissivism is a thesis about epistemic normativity, whereas doxastic voluntarism is a descriptive, psychological thesis. And it seems false that being permitted to do something entails an ability to do that thing or that one has control over that thing. For example, I may be permitted to buy you lunch, but cannot do so if I am broke. ${ }^{19}$

In response, I agree that permitted-to does not imply can; there are many situations, especially in the case of action, where one is permitted to do something but cannot because of various barriers, including lack of money, lack of resources, lack of knowledge, etc. Thus, my argument, if successful, cannot rest on this general principle. However, some of the barriers in the action case don't apply to the belief case; for example, lack of money or lack of resources don't normally prevent us from believing things. As Williams (1973) points out, one of the main barriers to changing your beliefs is because it's difficult (if not impossible) to believe something that is clearly false or irrational. This style of argument is given by many in the doxastic voluntarism literature (see Roeber, 2019 for a helpful survey), which suggests that when it comes to belief (and perhaps other mental states), normative factors have implications for descriptive factors.

The permissive cases I have in mind are cases in which two doxastic attitudes are rationally live for a single person, so they are torn about what to believe. So, in addition to being in a permissive case, the people in these cases are aware of their normative situation. Furthermore, there aren't other epistemic or practical barriers to their believing $p$ (e.g. they haven't previously committed to refrain from believing $p$ ). Thus, permitted-to does not imply can in general, nor does permitted-to-believe imply can-believe. However, in permissive cases in which other conditions are met (the person is aware of their normative situation, feels genuinely torn between two attitudes, and there aren't other epistemic or practical barriers), I maintain that one can exercise direct or semi-direct control over the belief in question. Further, note that even when someone is in a permissive case but is settled on a particular attitude, they can exercise semi-direct control to put themselves in a situation they have more control over their beliefs. For example, they might choose to reflect on their normative situation and realize their evidence is permissive, they might remove a practical barrier to believing (e.g. by choosing to give up or make a commitment), they might focus on part of their evidence, or they might deliberate in a particular way. Thus, as Claim 2 says, if permissivism is true, then people often have direct or semidirect control over their theistic beliefs-and, by exercising semi-direct control, they

19 Thanks to an anonymous referee for raising this objection. 
can remove various barriers to changing their doxastic attitudes. Then, they can put themselves in a situation where adopting either attitude is a live option for them.

This response implies that, to exercise the relevant kind of control, people need access to facts about their epistemic situation-at least on some level. This doesn't require that they study the permissivism/uniqueness debate or have the concept of "evidential underdetermination." But it does require that it is sometimes possible to know when one is in a permissive case, even if under a different guise-e.g. one might think: this is a hard question; my evidence is "inconclusive" or "balanced" or "leaves things open."20

A second worry one might have about my arguments in this section has to do with why many initially find doxastic involuntarism so compelling-not only has it been the dominant view among epistemologists and action-theorists, but it also simply seems to many that they can't control their beliefs in this way. A few things to note about this. First, I suspect doxastic involuntarism is a dogma among philosophers, but not more generally. In my and my colleagues' experiences in teaching and doing public philosophy, students and non-philosophers aren't nearly as quick to assume involuntarism as philosophers. While, admittedly, this claim needs further empirical verification, many students are initially open to the idea that they have a robust kind of control over their beliefs, especially if you don't begin with examples like giving them $\$ 1,000$ to believe that $1+1=3$. Thus, the possibility that doxastic involuntarism is, for contingent reasons, a philosophers' dogma should be explored-in part, via empirical tests.

Second, in many cases, we haven't sufficiently reflected on our epistemic situation. Sometimes, we may exercise control but not see the epistemic ramifications of this. For instance, many modern-day cases of religious conversion are similar to van Inwagen's duck-rabbit example, and are not cases of suddenly receiving overwhelming evidence. They are much more like a choice than like the evidence forcing your hand. ${ }^{21}$ I suspect that philosophers either overlook this or fail to realize its implications for doxastic voluntarism. Finally, it's plausible that believing that doxastic involuntarism is true makes it more difficult to exercise control over one's beliefs - in the same way that genuinely believing you cannot, say, make a shot in a basketball game, perform well in a Q\&A, or complete a difficult task on time, makes it more likely you cannot do those things (if you believe you cannot, you may not

\footnotetext{
${ }^{20}$ Thanks to Marc-Kevin Daoust. While many permissivists think one can normally know when they are in a permissive case, see Smith (2020) for an exception. It's also worth noting that people may also have doxastic control if they merely believe that they are in a permissive case, even if their case is not permissive. My claim is not that known permissive cases are the only cases in which we may have this sort of control; we may have control in merely believed permissive cases and even some non-permissive cases (e.g. a psychologist helps a subject to see that their evidence clearly points to $\mathrm{p}$ to help them overcome their delusional belief that not-p).

21 See Clark (1993), Ang (2019), Morris (1994), especially Jordan's essay, Vitz \& Hatfield (2012), especially Cuneo's essay, and Besong and Fuqua (2019), especially Cutter's essay. St. Augustine (397400/1998) also discusses a period in his conversion similar to van Inwagen's, in which the evidence for and against Christianity seemed equal to him. C.S. Lewis (1952: 123) similarly remarks, "Now that I am a Christian I do have moods in which the whole thing looks very improbable: but when I was an atheist I had moods in which Christianity looked terribly probable."
} 
even try). Since most philosophers believe that doxastic involuntarism is true, they are less likely to exercise robust doxastic control. So they may rarely, if ever, personally exercise direct or semi-direct control over their beliefs.

\section{The Irrationality Objection}

\subsection{The Objection}

Thus far, we've seen that, if intrapersonal permissivism is true, then we have direct or semi-direct control over our beliefs. However, this is separable from the question of whether the beliefs that result from exercising this control are epistemically rational. And forming a belief for a practical reason seems to call into question the epistemic status of the belief. If I form a belief because I want it to be true, or because it would maximize expected value on a traditional (i.e. non-epistemic) decision-theoretic calculation, that doesn't appear to be an epistemically good basis for belief. The case starts to look like wishful thinking, or simply holding a belief because it brings a practical benefit. Thus, even if we can form beliefs as a result of taking Pascal's wager, it's not clear that beliefs formed as a result of wagering would be epistemically rational.

This general line of reasoning is pushed by several in the literature, including Clifford (1877), Flew (1976), Mackie (1982), Oppy (1991: 167), and Schroeder (2012: 266). For instance, W.K. Clifford famously said, "It is wrong always, everywhere, and for anyone, to believe anything upon insufficient evidence" (1877: 289). Similarly, when discussing the wager, Antony Flew remarks, "Deliberately to set about persuading yourself of the truth of a conclusion which is not warranted by the available evidence is flatly to reject... a principle fundamental to personal and intellectual integrity" (1976: 64). J.L Mackie agrees that this is a serious problem for the wager: "Deliberately trying to make oneself believe, by such techniques as [Pascal] suggests-essentially by playing tricks on oneself that are found by experience to work upon people's passions and to give rise to belief in non-rational ways-is to do violence to one's reason and understanding" (1982: 202). One might even argue that evidentialism - a popular and orthodox view in epistemology that says one epistemically ought to proportion one's beliefs to the evidence (see Feldman \& Conee, 1985; Conee \& Feldman, 2004; McCain, 2014, 2018)—would conflict with what Pascal's wager prescribes, since the wager focuses on the practical benefits of believing in God, rather than evidence that God exists.

\subsection{The Concessive Responses}

An initial concessive response agrees the beliefs formed as a result of taking Pascal's wager are epistemically irrational: from an epistemic point of view, we should not have these beliefs. Nonetheless, the epistemic isn't the only point of view by which we might evaluate beliefs. We might evaluate beliefs for their practical 
benefits, for their moral goodness or rightness, or even from an all-things-considered perspective. For instance, suppose someone believes that they are smarter than average. Even if their evidence doesn't support it, the belief might raise their self-esteem and thus be practically beneficial. Or one might have a lot of (misleading) evidence for a belief that is sexist or racist, e.g. that people of a certain race are bad tippers. Even if the belief is epistemically justified, it is morally impermissible. All-thingsconsidered oughts (if they exist) take epistemic, moral, practical, (etc.) oughts as inputs. So for instance, it seems all-things-considered impermissible to have sexist or racist beliefs, even if they are epistemically justified, as the moral reasons seem to outweigh the epistemic reasons.

Borrowing from this framework, some have suggested that, while the wagerer's beliefs might be epistemically irrational, they are nonetheless practically or morally justified (see Jackson, 2016; Jackson \& Rogers, 2019). Since plausibly, practical and moral oughts often or always trump epistemic oughts, then the wagerer's beliefs would also be all-things-considered rational. Thus, Pascalian beliefs are rational from several perspectives, even if not epistemically. This response, while interesting, concedes that the wagerer's belief is epistemically irrational.

A second potential response is to endorse a version of pragmatic encroachment- the idea that the practical can affect epistemic rationality (see Kim, 2017). On a popular version of pragmatic encroachment, practical stakes can change the level of evidence required for a belief to be rational. While most versions of pragmatic encroachment focus on the idea that if the stakes get higher, the evidential bar for epistemic rationality is raised, it's also possible for the practical to lower the bar, making it easier for a belief to be rational than it otherwise would be. ${ }^{22}$ Benton (2018) explores the possibility that Pascalian practical reasons might make it easier to be epistemically rational as a theist than as an atheist. This possibility, while interesting, requires us to accept the controversial idea that pragmatic factors affect epistemic rationality. I'll suggest a way to reply to the irrationality objection that secures the epistemic rationality of the wagerer's belief, and does so without forcing us to commit to pragmatic encroachment.

\subsection{The Powerful Permissive Response}

If intrapersonal permissivism is true, this leaves us with a more powerful response to the irrationality objection - one that does not concede that the wagerer's beliefs are epistemically irrational or require pragmatic encroachment. In intrapersonally permissive cases, the epistemic 'leaves things open.' More than one attitude is rationally available to the believer-she can hold either attitude and be epistemically rational. Thus, if someone finds herself in a permissive case where her evidence permits believing $\mathrm{p}$, withholding belief on $\mathrm{p}$, and disbelieving $\mathrm{p}$, and she decides to believe $\mathrm{p}$, it's hard to see on what grounds we could say she's done anything wrong,

$\overline{22}$ Thanks to an anonymous referee for suggesting this possibility. 
epistemically. In fact, given her permissive situation, her attitude is by definition rational! This brings us to our third claim:

Claim 3: If there are relatively common evidential situations in which a single person can rationally adopt more than one belief-attitude toward the proposition God exists, then, in those cases, theistic beliefs formed for Pascalian reasons are epistemically rational.

Two clarifications about Claim 3. First, belief that God exists must fall under the person's epistemically permitted attitudes. There may be cases where someone is permitted to be either an atheist or an agnostic, but their evidence rules out theism. These cases aren't our primary concern. Recall we're focused on people for whom theism is a live epistemic possibility. And in Sect. 3, I argued that many people are epistemically permitted to be theists, given their evidence. If one's evidence truly rules out theism but permits atheism and agnosticism, then one can take the first step toward wagering by choosing to be an agnostic rather than an atheist, then gather evidence and exercise long-range control to raise the probability of becoming a theist. This case, however, isn't our focus. A second clarification involves the phrase "beliefs formed for Pascalian reasons." Meta-ethicists distinguish different kinds of reasons - three of which are motivating reasons (facts for which someone phi-s), normative or justifying reasons (that count in favor of phi-ing), explanatory reasons (that explain why someone phi-ed). The most natural interpretation of forming a belief for some reason picks out a motivating reason. However, the cases I'm concerned with are permissive, so people genuinely have the relevant normative reason, too. ${ }^{23}$ Thus, I am concerned with both motivating and normative reasons-people that believe for Pascalian reasons that count in favor of that belief.

I defend Claim 3 in two steps. First, I address the epistemic status of adopting a permitted attitude for a practical reason; then, I examine whether this conflicts with evidentialism. On the first, suppose my evidence permits both theism and agnosticism and I have Pascalian reasons to be a theist. My normative situation is thus one on which my epistemic reasons permit theism, and my practical reasons require theism. Suppose I'm aware of these normative facts, and I choose to be a theist. ${ }^{24}$ Does this call into question the epistemic status of my belief? I see no reason to think so. Theism is perfectly epistemically rational for me; since the epistemic leaves things open, I should be able to pick theism without compromising epistemic rationality.

\footnotetext{
${ }^{23}$ Some argue that there aren't practical (normative) reasons for belief, as practical reasons are a "wrong kind" reason. While I cannot fully address this view here, one of the main arguments for this claim is that practical reasons cannot motivate people to believe things (thus, in this case, being a motivating reason for belief is necessary for being a normative reason; see Shah 2003; 2006). I've given an extensive argument and series of cases in which the practical motivates belief in Sect. 3.3. Further, I suspect those arguing against practical reasons for belief aren't focused on epistemically permissive cases, and this possibility changes the landscape. See Leary $(2017)$ and Rinard $(2018 ; 2019)$ for extended defenses of the claim that there are normative and motivating practical reasons for belief.

24 Again, recall I'm assuming that unacknowledged permissivism is false. See fn. 20.
} 
Suppose instead that I choose a permitted attitude at random, rather than for a practical reason. Is this any epistemically better? If arbitrarily adopting an attitude is epistemically permitted, then practical tiebreakers also appear permissible. If I'm genuinely in a permissive case, then it is hard to see-without further argumentwhy practical tiebreakers would result in epistemic irrationality.

Let's suppose that the objector insists that practical reasons, even to break epistemic ties, cause epistemically irrational belief. Even on this extreme view, the objector's claim is importantly limited. Philosophers distinguish between propositional justification - having justification to believe $\mathrm{p}$ - and doxastic justificationhaving a justified belief that . $^{25}$ For example, if one's evidence supports $\mathrm{p}$, but one believes $\mathrm{p}$ based on wishful thinking, one's belief that $\mathrm{p}$ is propositionally, but not doxastically, justified. In our case, if believing God exists is perfectly rational, given one's evidence, but one believes in God exists (in part) for a practical reason, one's belief is still propositionally justified. One's evidence justifies theistic belief. So this objection would establish, at most, that one's belief is doxastically unjustified-the belief is nonetheless, in some important sense, rational or justified. Even on a fairly concessive picture, then, Pascalian beliefs formed in permissive cases are propositionally justified.

Second, one might wonder if wagering in permissive cases violates evidentialism. ${ }^{26}$ A classic statement of evidentialism is that one epistemically ought to proportion one's beliefs to one's evidence. ${ }^{27}$ Whether the wagerer violates evidentialism depends on the reason that they are in a permissive case. I'll argue that on one way of motivating permissivism, the wagerer won't violate evidentialism. On another way of motivating permissivism, the wagerer violates evidentialism, but we also have good reason to think that evidentialism is false.

Titelbaum and Kopec (2019: 206) distinguish between different versions of the uniqueness thesis (uniqueness is the denial of permissivism). Borrowing from their distinctions, we can distinguish two ways of motivating permissivism. On a 'propositional' motivation, some bodies of evidence don't uniquely support a proposition or its negation, nor are they perfectly balanced between the two, supporting neither. This is a claim about evidence. Roeber $(2019,2020)$ motivates this version of permissivism by focusing on cases where evidence is initially balanced between $\mathrm{p}$ and not-p, but slowly builds and eventually supports p. At some point during this process, Roeber argues, the evidence neither uniquely supports $\mathrm{p}$ (nor not-p), nor is it 'balanced' (recall his bird/bag example). Their evidence rules out disbelief but permits both belief and withholding belief. On this motivation for permissivism, people in permissive cases who believe for Pascalian reasons aren't violating evidentialism. Insofar as their evidence supports a proposition, they are proportioning their beliefs

\footnotetext{
25 The distinction between propositional and doxastic justification was originally introduced by Firth (1978); see Silva \& Oliveira (forthcoming) for an introduction to the distinction. Note that I'm using 'rational' and 'justified' interchangeably.

26 Thanks to Josh Brecka.

27 This understanding of evidentialism goes back to Locke (1689: book IV, ch. XVI). However, alternative definitions of evidentialism interact with permissivism differently; see Kopec \& Titelbaum (2016: 193) and Jackson \& Turnbull (forthcoming) for discussion.
} 
to the evidence. In this case, both belief and withholding belief are equally supported by the evidence, so adopting either attitude is a way of proportioning one's beliefs to the evidence; only disbelieving would violate evidentialism.

A second, 'personal' motivation for permissivism is consistent with the idea that one's evidence supports a unique attitude toward a proposition. Suppose that someone's evidence is quite complicated. Even though her evidence supports a unique proposition, she can't be held responsible for seeing that, and thus she will "clear the bar" for rationality even if she takes another attitude. Maybe her evidence is so opaque that, even after she has done her epistemic duties and extensively evaluated her evidence, from her perspective, there is no epistemic difference between believing $\mathrm{p}$ and being agnostic about $\mathrm{p}$. Unlike the propositional motivation, this isn't necessarily a claim about evidence, but a claim about what one is rationally allowed to conclude from their evidence. On this motivation, people in permissive cases who believe for Pascalian reasons violate evidentialism, but respecting evidentialism isn't rationally required. Since the evidence is so complex, one cannot access what the evidence supports, and thus is not required to proportion their beliefs to the evidence. This reading is inconsistent with evidentialism, but this isn't problematic, since evidentialism isn't well-motivated.

I close this section with a final point about adopting an epistemically permitted attitude for a practical reason. White $(2005,2013)$ argues that intrapersonal permissivism is problematic because it allows toggling - moving between permitted attitudes at random. White discusses randomly changing attitudes, and notes, "Each time I toggle my beliefs in this manner I am relieved to find that my resulting opinion is true. The absurdity of this should make us wonder whether permissive cases are possible" (2013: 317). Random toggling between attitudes seems epistemically irrational, but White argues that the permissivist does not have the resources to explain why (see also Hedden, 2015).

Practical reasons open up a response to White on behalf of the intrapersonal permissivist. Suppose that my epistemic reasons permit both believing $\mathrm{p}$ and withholding belief on $\mathrm{p}$. If we focus on the epistemic, then prima facie, toggling seems problematic. However, if I have a decisive practical reason to believe $\mathrm{p}$, and no such practical reason to withhold belief, then toggling is no longer permitted, unless my practical reasons change. And toggling due to a change in reasons doesn't seem irrational. Believing for a practical reason might even be epistemically better than picking a permitted attitude at random. Thus, when practical reasons are at play, the permissivist has the resources to explain the irrationality of toggling. ${ }^{28}$

We've seen that, in intrapersonally permissive cases, people can form beliefs for practical reasons without their beliefs being epistemically irrational. Further, this violates evidentialism only when evidentialism is implausible.

\footnotetext{
${ }^{28}$ Roeber (2020) and Jackson (2021) offer alternative responses to the toggling worry that apply when practical reasons are not at play.
} 


\section{Conclusion}

I've argued that, if intrapersonal permissivism is true, there are powerful responses to two objections to Pascal's wager. In response to the impossibility objection, in permissive cases, one has direct or semi-direct control over one's theistic beliefs. In response to the irrationality objection, if one is in a permissive case, adopting a permitted attitude isn't epistemically irrational, even if done in part for practical reasons. Thus, the defender of the wager has good reason to take on board a permissive epistemology.

On this picture, theism and atheism are epistemically symmetrical; our evidence doesn't privilege one over the other. However, insofar as Pascal's wager is successful, they might be practically asymmetrical. While of course, I haven't fully argued for the success of Pascal's reasoning, it is noteworthy that, even if theism and atheism are epistemically on a par, there may be other ways to break the apparent tie.

Acknowledgements Thanks to two anonymous referees at this journal, Marc-Kevin Daoust, Kirk Lougheed, Jack Warman, Derek McAllister, and audiences at the 2015 Society of Christian Philosophers meeting at Messiah College, the 2018 Evangelical Philosophical Society in Denver, and the 2019 Canadian Philosophical Association in Vancouver for helpful questions and comments on this paper.

\section{References}

Adler, J. (2002). Belief's Own Ethics. MIT Press.

Alston, W. (1988). The deontological conception of epistemic justification. Philosophical Perspectives, 2, 257-299.

Ang, D. (2019). A Scientist Looks at the Resurrection. Peaceful Science. Available at: https://peacefulsc ience.org/daniel-ang-a-scientist-looks-at-the-resurrection/.

Augustine, Saint. (1998). The Confessions (M. Boulding, trans.). (pp 397-400). New York: Vintage Books.

Bartha, P. (2012). Many Gods, Many Wagers: Pascal's Wager Meets the Replicator Dynamics. In J. Chandler \& V. S. Harrison (Eds.), Probability in the Philosophy of Religion (pp. 187-206). Oxford University Press.

Bennett, J. (1990). Why is belief involuntary? Analysis, 50(2), 87-107.

Benton, M. (2018). Pragmatic Encroachment and Theistic Knowledge. In M. A. Benton, J. Hawthorne, \& D. Rabinowitz (Eds.), Knowledge, Belief, and God: New Insights in Religious Epistemology (pp. 267-287). Oxford University Press.

Besong, B., \& Fuqua, J. (2019). Faith and Reason: Philosophers Explain Their Turn to Catholicism. Ignatius Press.

Buckareff, A. A. (2004). Acceptance and deciding to believe. Journal of Philosophical Research, 29, 173-190.

Callahan, Laura. (Forthcoming). Epistemic existentialism. Episteme. https://doi.org/10.1017/epi.2019.25.

Chen, E., \& Rubio, D. (2020). Surreal decisions. Philosophy and Phenomenological Research, 100(1), 54-74.

Clark, K. J. (1993). Philosophers Who Believe: The Spiritual Journey of 11 Leading Thinkers. Intervarsity Press.

Clifford, W. K. (1877). The ethics of belief. Contemporary Review, 29, 289-309.

Cockayne, J., Efrid, D., Molto, D., Tamburro, R., \& Warman, J. (2017). Non-evidential believing and permissivism about evidence: a reply to Dan-Johan Eklund. Religious Studies, 53(1), 87-95.

Conee, E., \& Feldman, R. (2004). Evidentialism. Oxford University Press.

Cullison, A. (2010). Two solutions to the problem of divine hiddenness. American Philosophical Quarterly, 47(2), 119-134. 
Dogramaci, S., \& Horowitz, S. (2016). An argument for uniqueness about evidential support. Philosophical Issues, 26, 130-147.

Duff, A. (1986). Pascal's wager and infinite utilities. Analysis, 46, 107-109.

Duncan, C. (2018). The Many-Gods Objection to Pascal's Wager: A Defeat, then a Resurrection. In Pascal's Wager (P. Bartha and L. Pasternack, eds.). Cambridge: CUP.

Feldman, R. (2001). Voluntary Belief and Epistemic Evaluation. In M. Steup (Ed.), Knowledge, Truth, and Duty: Essays on Epistemic Justification, Responsibility, and Virtue (pp. 77-92). OUP.

Feldman, R., \& Conee, E. (1985). Evidentialism. Philosophical Studies, 48(1), 15-34.

Felipe, M. (2020). On the epistemic significance of agreement with exceptional theistic philosophers. Faith and Philosophy., 37(4), 451-474.

Firth, R. (1978). Are Epistemic Concepts Reducible to Ethical Concepts? In A. Goldman \& J. Kim (Eds.), Values and Morals (pp. 215-299). D. Reidel.

Flew, A. (1976). The Presumption of Atheism and Other Philosophical Essays on God, Freedom, and Immortality. Harper and Row.

Frankish, K. (2007). Deciding to believe again. Mind, 116(463), 523-547.

Ginet, C. (2001). Deciding to Believe. In M. Steup (Ed.), Knowledge, Truth and Duty: Essays on Epistemic Justification, Responsibility, and Virtue (pp. 63-76). OUP.

Golding, J. (1994). Pascal's wager. The Modern Schoolman, 71(2), 115-143.

Greco, D., \& Hedden, B. (2016). Uniqueness and metaepistemology. The Journal of Philosophy, 113(8), $365-395$.

Hájek, A. (2003). Waging war on Pascal's wager. The Philosophical Review, 112(1), 27-56.

Hedden, B. (2015). Time-slice rationality. Mind, 124(494), 449-491.

Hick, J. (1966). Evil and the God of Love. Harper and Row.

Hieronymi, P. (2006). Controlling attitudes. Pacific Philosophical Quarterly, 87(1), 45-74.

Hieronymi, P. (2009). Believing at will. The Canadian Journal of Philosophy, Supplementary, 35(1), 149-187.

Howard-Snyder, D., \& Moser, P. K. (Eds.). (2002). Divine Hiddenness: New Essays. CUP.

Jackson, E. (2016). Wagering against divine hiddenness. The European Journal for Philosophy of Religion, 8(4), 85-105.

Jackson, E. (2019). Belief and credence: why the attitude-type matters. Philosophical Studies, 176(9), 2477-2496.

Jackson, E. (2021). A defense of intrapersonal belief permissivism. Episteme, 18(2), 313-327.

Jackson, E., \& Rogers, A. (2019). Salvaging Pascal's wager. Philosophia Christi, 21(1), 59-84.

Jackson, E., Turnbull, M. G. (Forthcoming). Permissivism, Underdetermination, and Evidence. In The Routledge Handbook for the Philosophy of Evidence (Clayton Littlejohn and Maria LasonenAarnio, eds.). New York: Routledge.

James, W. (1896). The Will to Believe. In The Will to Believe and Other Essays (F. Burkhardt et al., eds.), pp 2-32. Cambridge, MA: Harvard University Press.

Jones, W. (1998). Religious conversion, self-deception, and Pascal's wager. Journal of the History of Philosophy, 36, 167-188.

Jordan, J. (1991). The many-gods objection and Pascal's wager. The International Philosophical Quarterly, 31, 309-317.

Jordan, J. (2006). Pascal's Wager: Pragmatic Arguments and Belief in God. OUP.

Kelly, Thomas. (2013). Evidence Can Be Permissive. Contemporary Debates in Epistemology, 2nd ed. (M. Steup, J. Turri, and E. Sosa, eds.), pp 298-311. Hoboken: John Wiley \& Sons.

Keysar, Ariela, Navarro-Rivera, Juhem. (2017). A World of Atheism: Global Demographics. In The Oxford Handbook of Atheism (Stephen Bullivant and Michael Ruse, eds.). Oxford: OUP.

Kim, Brian. (2017). Pragmatic encroachment in epistemology. Philosophy Compass, 12(5), 1-14.

Kopec, M. (2015). A counterexample to the uniqueness thesis. Philosophia, 43, 403-409.

Kopec, M., \& Titelbaum, M. (2016). The uniqueness thesis. Philosophy Compass, 11(4), 189-200.

Leary, S. (2017). In defense of practical reasons for belief. Australasian Journal of Philosophy, 95(3), $529-542$.

Lewis, C. S. (1952). Mere Christianity. Geoffrey Bles.

Locke, J. (1689). An Essay Concerning Human Understanding. London.

Lycan, W., \& Schlesinger, G. (1989). You Bet Your Life: Pascal's Wager Defended. In Reason \& Responsibility, 7th edition (Joel Feinberg, ed.). Belmont, CA: Wadsworth.

Mackie, J. L. (1982). The Miracle of Theism: Arguments for and against the Existence of God. OUP.

Martin, M. (1975). On four critiques of Pascal's wager. Sophia, 14, 1-11. 
Matheson, J. (2011). The case for rational uniqueness. Logos \& Episteme, 2, 359-373.

McBrayer, J. P., \& Howard-Snyder, D. (Eds.). (2013). The Blackwell Companion to the Problem of Evil. John Wiley and Sons.

McCain, K. (2014). Evidentialism and Epistemic Justification. Routledge.

McCain, K. (2018). Believing in Accord with the Evidence: New Essays on Evidentialism. Springer.

McHugh, C. (2013). The illusion of exclusivity. European Journal of Philosophy, 23(4), 1117-1136.

McHugh, C. (2014). Exercising doxastic freedom. Philosophy and Phenomenological Research, 88(1), $1-37$.

Mizrahi, M. (2013). New puzzles about divine attributes. European Journal for Philosophy of Religion, $5(2), 147-157$.

Morris, T.V., (1994). God and the Philosophers: The Reconciliation of Faith and Reason. Oxford: OUP.

Murray, M. (2002). Deus Absconditus. In D. Howard-Snyder \& P. K. Moser (Eds.), Divine Hiddenness: New Essays (pp. 63-75). CUP.

Nickel, P. J. (2010). Voluntary belief on a reasonable basis. Philosophy and Phenomenological Research, $81(2), 312-334$.

Nottelmann, N. (2006). The analogy argument for doxastic voluntarism. Philosophical Studies, 131, $559-582$.

Oppy, G. (1991). On Rescher on Pascal's wager. The International Journal for Philosophy of Religion, $30,159-168$.

Pascal, B. (1662). Pensees. Translated by W. Trotter, New York: J. M. Dent Co., 1958, fragments 233-241.

Peels, R. (2015). Believing at will is possible. Australasian Journal of Philosophy, 93(3), 524-541.

Pittard, J. (2020). Credal Voluntarism and the Christian Faith. Unpublished Manuscript.

Plantinga, A. (1993). Warrant: The Current Debate. OUP.

Podgorski, A. (2016). Dynamic permissivism. Philosophical Studies, 173, 1923-1939.

Raleigh, T. (2017). Another argument against uniqueness. The Philosophical Quarterly, 67(267), $327-346$.

Raz, J. (1999). Engaging Reasons. Oxford University Press.

Rinard, S. (2018). Believing for practical reasons. Nô̂s, 4, 763-784.

Rinard, S. (2019). Equal treatment for belief. Philosophical Studies, 176(7), 1923-1950.

Roeber, B. (2019). Evidence, judgment, and belief at will. Mind, 128(511), 837-859.

Roeber, B. (2020). Permissive situations and direct doxastic control. Philosophy and Phenomenological Research, 101(2), 415-431.

Rota, M. (2016a). A better version of Pascal's wager. American Catholic Philosophical Quarterly 101(2): $415-439$.

Rota, M. (2016b). Taking Pascal's Wager: Faith, Evidence, and the Abundant Life. Downers Grove, IL: InterVarsity Press.

Russell, B. (2001). Epistemic and Moral Duty. In M. Steup (Ed.), Knowledge, Truth and Duty: Essays on Epistemic Justification, Responsibility, and Virtue (pp. 34-62). OUP.

Ryan, S. (2003). Doxastic compatibilism and the ethics of belief. Philosophical Studies, 114, 47-79.

Schellenberg, J. L. (1993). Divine Hiddenness and Human Reason. Cornell University Press.

Schoenfield, M. (2014). Permission to believe: why permissivism is true and what it tells us about irrelevant influences on belief. Noûs, 48, 193-218.

Schoenfield, M. (2019). Permissivism and the value of rationality: a challenge to the uniqueness thesis. Philosophy and Phenomenological Research, 99(2), 286-297.

Schroeder, M. (2012). Stakes, withholding, and pragmatic encroachment on knowledge. Philosophical Studies, 160, 265-285.

Scott-Kakures, D. (1994). On belief and the captivity of the will. Philosophy and Phenomenological Research, 54(1), 77-103.

Setiya, K. (2008). Believing at will. Midwest Studies in Philosophy, 32(1), 36-52.

Shah, N. (2003). How truth governs belief. The Philosophical Review, 112(4), 447-482.

Shah, N. (2006). A new argument for evidentialism. The Philosophical Quarterly, 56(225), 481-498.

Shah, N., \& Velleman, D. (2005). Doxastic deliberation. The Philosophical Review, 114(4), 497-534.

Silva, P., \& Oliveria, L. R. G. (Forthcoming). Propositional Justification and Doxastic Justification. In The Routledge Handbook of the Philosophy of Evidence (Clayton Littlejohn and Maria LasonenAarnio, eds.). New York: Routledge.

Smith, J. J. (2020). Unacknowledged permissivism. Pacific Philosophical Quarterly, 101(1), 158-183.

Steup, M. (2012). Belief control and intentionality. Synthese, 188, 145-163. 
Steup, M. (2017). Believing intentionally. Synthese, 194, 2673-2694.

Swinburne, R. (1979). The Existence of God. Oxford: Oxford University Press

Sylvan, K. (2016). The illusion of discretion. Synthese, 193, 1635-1665.

Titelbaum, M., \& Kopec, M. (2019). When Rational Reasoners Reason Differently. In M. Balcerak-Jackson \& B. Balcerak-Jackson (Eds.), Reasoning: Essays on Theoretical and Practical Thinking (pp. 205-231). Oxford University Press.

Van Inwagen, P. (1994). Quam Dilecta. God and the Philosophers: The Reconciliation of Faith and Reason (T. V. Morris, ed.), pp 31-60. Oxford: OUP.

Vitz, R., \& Hatfield, C. (Eds.). (2012). Turning East: Contemporary Philosophers and the Ancient Christian Faith. St. Vladimir's Seminary Press.

Walls, J., \& Dougherty, T. (Eds.). (2018). Two Dozen (or so) Arguments for God: The Plantinga Project. OUP.

White, R. (2005). Epistemic permissiveness. Philosophical Perspectives, 19, 445-459.

White, R. (2013). Evidence Cannot be Permissive. In Contemporary Debates in Epistemology, 2nd Edition (Ernest Sosa and John Turri eds.), pp 312-323. Hoboken, NJ: Wiley Blackwell.

Wielenberg, E. (2009). Dawkins's gambit, Hume's aroma, and God's simplicity. Philosophia Christi, $11(1), 113-127$.

Williams, B. (1973). Deciding to Believe. In B. Williams (Ed.), Problems of the Self (pp. 136-151). CUP.

Winters, B. (1979). Believing at will. The Journal of Philosophy, 76(5), 243-256.

Publisher's Note Springer Nature remains neutral with regard to jurisdictional claims in published maps and institutional affiliations. 